\title{
ENERGY EFFICIENCY FOR AIRPORT INFRASTRUCTURE: A CASE STUDY OF THE IMPLEMENTATION OF ENERGY EFFICIENCY FOR AIRPORTS IN SOUTH AFRICA
}

\author{
JERUSHA JOSEPH \& FREDDIE INAMBAO* \\ Department of Mechanical Engineering, University of KwaZulu-Natal, Durban, South Africa
}

\begin{abstract}
Achieving energy efficiency sustainably for a site involves the elimination of energy wastage, reduction in carbon footprint and reduction in operational costs while at the same time achieving standardization across operations and maintenance practices. Achieving energy efficiency with the current climate change crisis requires that energy efficiency be established from energy source to end user. Energy efficiency for a site also involves ensuring that energy intensive equipment, plant and other devices are consuming as little energy as possible, while maximizing their work output. This paper presents the groundwork completed in the process of transitioning airports in South Africa to being energy efficient.

KEYWORDS: Energy efficiency in Developing Countries, Energy Savings, Energy Conservation, Forms of Energy, Energy Conversion Efficiencies, Energy Management, Standards and Guidelines for Energy Efficiency \& Holistic Approach to Energy Efficiency
\end{abstract}

Received: Jan 18, 2021; Accepted: Feb 08, 2021; Published: Mar 22, 2021; Paper Id.: IJMPERDAPR202128

\section{INTRODUCTION}

One of the most attractive benefits to improvement in energy efficiency in buildings is lower energy costs. Other benefits likely to be realized from energy efficiency investments in buildings are:

- $\quad$ Reducing energy use for space heating and/or cooling and water heating;

- Reduced electricity use for lighting, office machinery and domestic type appliances;

- $\quad$ Reduced maintenance requirements;

- Improved comfort;

- Enhanced property value.

The importance of energy efficiency in the building sector is especially significant in developing countries owing to the increase in new construction with opportunities to employ efficient materials and best practices. [1]

The first principle of energy efficiency as outlined by [2] requires the efficient matching of energy source to energy need resulting in the shortest energy conversion route from the energy source to the energy need and that the energy source is the best choice for cost effectiveness, satisfaction of the need, and closeness to zero carbon emissions. The second principle of energy efficiency as outlined by [2] requires that a holistic approach be taken when it comes to energy efficiency, which means considering the energy consuming device or technology, the 
system that the device or technology is a part of, as well as factors affecting the system and factors affected by the system. The third principle states that one must ensure that implementation of energy efficiency meets business imperatives and supports operations, culminating in a "Standards and Guidelines for Energy Efficiency" document that can be adopted as a policy by the site/organization. These standards and guidelines must include device types, system types and preferred designs that will apply when new buildings and facilities are constructed, and replacement cycles for existing buildings and facilities are executed.

This paper presents the application of these principles for the airports in South Africa owned and operated by Airports Company South Africa to begin the transformation of the airports to be energy efficient over the course of a specific period of time. The paper presents the implemented approach to energy efficiency to ensure that airports are transitioned to energy efficient operations and infrastructure reducing energy wastage. The matching of low carbon energy sources to the energy need is presented with consideration of the operating environments, commercial markets, staff technical acumen and business imperatives. The "Standards and Guidelines for Energy Efficiency"document to be adopted as a policy for airports to transition towards energy efficiency is presented together with the principles from which they were derived.

\section{APPLYING THE PRINCIPLES OF ENERGY EFFICIENCY FOR AIRPORTS}

The energy consumption of airports in South Africa, specifically the O R Tambo International Airport, Cape Town International Airport, King Shaka International Airport, Port Elizabeth International Airport, East London Airport, Bram Fischer International Airport, George Airport, Upington International Airport and Kimberley Airport, have a characteristically high base load (at least 50\%). Their significant energy users are lighting (about 50\% to 60\%) and air conditioning (20\% to $30 \%$ ) and a significant number of pumps motors and fans. [3]

The airports' energy needs for their buildings and infrastructure are primarily satisfied by electricity supplied by South Africa's national electricity provider, Eskom. Eskom derives most of its power from coal-fired power plants. The airports' mechanical road vehicles are fuelled with diesel and petroleum. Some of the airport sites use LPG for cooking at the various commercial restaurants. The focus of the application of energy efficiency is on the significant energy users that are carbon intensive, i.e., electricity consumption from the grid and specifically on significant energy users of the electricity.

\subsection{Finding the Most Suitable Energy Source to Match the Energy Need}

The first principle to achieving energy efficiency as per [2] is to ensure that the most suited energy source is selected to serve the energy need.

Principle One: Match energy source and energy need using the shortest energy conversion route from the energy source to the energy end use and ensure that the energy source is the best choice for cost effectiveness and is as close to zero carbon emissions as possible.

The airports' significant energy users are lighting and air conditioning. This principle is applied for these significant energy users.

\section{(a) Lighting}

The airport's most significant energy user is lighting. Lighting is used not just for terminal buildings, office buildings, 
commercial facilities such as hotels and transportation systems, car parks, streets, roads, and walkways, but also for the crucial purpose of lighting runways to assist aircraft to land and take-off safely. The lighting load being typically at least $50 \%$ of the airport's total load, the focus on ensuring that the lighting load is as efficient as possible is the key to reducing capital cost, carbon emissions and operational costs (including maintenance). Lighting is required during the day and at night for the terminal office and multi-storey parkades as well as the airfield including runways.

The best available technology for lighting that satisfies energy efficiency criteria is currently LED lighting. LED lighting technology consists of the same semiconductor materials that are used in solar photovoltaic technologies with different material treatments for performance according to its application (lighting or power generation). It will therefore be ideal to use solar energy to power the LED lighting that is needed during the daytime. It is the most efficient energy source for the energy need as it is the shortest route from the energy source to the energy end use and ensures that the energy source is the best choice for cost effectiveness and is as close to zero carbon emissions as possible (figure 1).

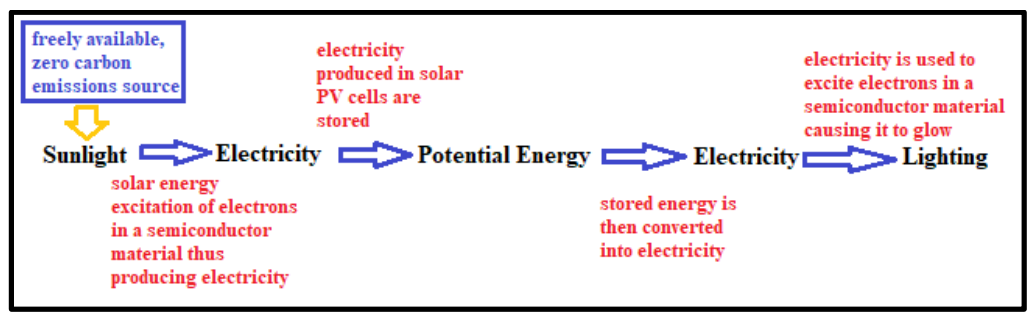

Figure 1: Solar Energy as an Energy Source for Lighting.

Figure 1 shows the typical commercially available solar powered LED lighting. It can be seen from the figure that there is one energy conversion between the same energy type, i.e., electricity is stored and then released. Energy storage is key for renewable energy sources such as solar energy and wind energy due to their availability being intermittent. At this stage, commercial storage options usually involve a battery pack and in commercial solar PV plants, the solar PV plant design includes energy storage or a grid-tie connection arrangement to overcome the intermittency related to solar energy. Technology development and lamp designs are yet to evolve to take advantage of direct conversion from solar energy to LED lighting.

\section{(b) Space Conditioning (Heating, Ventilation and Air Conditioning - HVAC)}

The second significant energy user at airports is for space conditioning. The demand for air conditioning is typically driven by the weather conditions; the higher the ambient temperature and thermal discomfort (high humidity), the greater the demand for space conditioning. Air conditioning involves two major energy users on the chilled water side, namely, the chillers and the cooling towers.

\section{(i) Chillers}

To produce chilled water, a refrigerant is compressed in a vapour compression cycle using a mechanical compressor which runs on electricity and is cooled by water (via cooling towers) or air (must be installed in an area where sufficient air intake is facilitated). The cooling output to electricity input (coefficient of performance or COP) of the commercial vapour compression chiller is usually between 3.0 and 3.8. Maintenance is the key to ensure that the COP of the chillers remains consistent during its useful life. 
Due to the demand for cooling being proportional to the ambient temperature, this presents an opportunity to use the solar energy causing the demand for cooling to create the cooling effect. This is possible with absorption chiller technology available on the commercial market which uses heat to produce chilled water through the adoption of an absorbent such as lithium bromide and preferably water as a refrigerant for environmental sustainability (although ammonia is another option). The heat needed to drive the absorption cooling cycle can be harnessed from solar energy via solar thermal collectors. Alternately, if waste heat is available from another process on site, this can be harvested to power the absorption cooling cycle. This will be the most efficient energy process as it is the shortest route from the energy source to the energy need and significantly reduces carbon emissions to almost zero in running the chiller, with only a minimal amount of electricity being required to run a small pump that circulates the working fluids (Fig. 2). The absorption chiller adopting water as a refrigerant means that there is no global warming potential associated with the technology as there is with conventional vapour compression chillers.

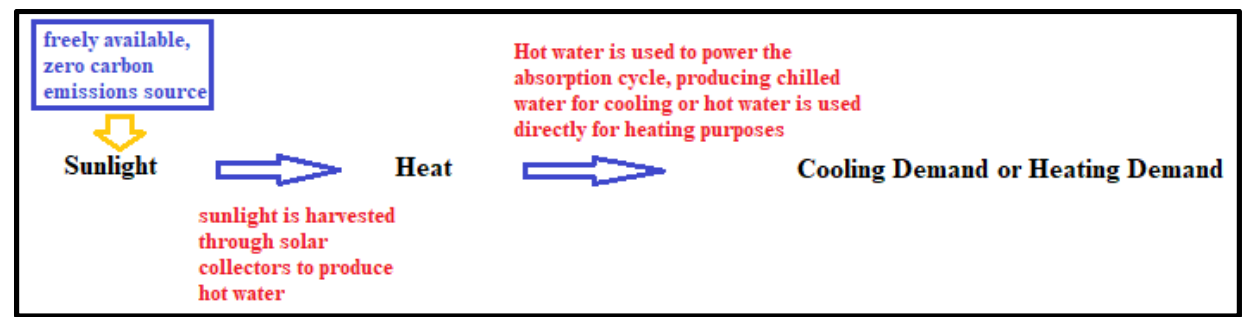

Figure 2: Solar Energy as an Energy source for Chillers in Air Conditioning Systems

A switch over valve within the absorption chiller allows for the solar heat harvested to be used for heating purposes. The technology for the solar thermal collector which harvests the solar heat should be chosen such that minimal heat is lost to the environment. Vacuum tube solar thermal collectors are most efficient in this respect. For larger commercial installations, utilizing solar energy may become a hurdle from a spatial point of view. Utilizing waste heat from a process plant (co-generation or trigeneration) may be a better arrangement to power absorption chillers in larger installations.

\section{(ii) Cooling Towers}

Cooling towers which are an integral part of ensuring that chilled water production is efficient by cooling the compressor through circulation of condenser water are another significant energy user in the air-conditioning system. Water-cooled chillers are intensive in energy and water consumption. Water loss due to evaporation in evaporative cooling towers in commercial size HVAC systems can make them expensive to operate. The energy consumption can also become increasingly expensive as the demand for cooling the condenser water increases. The energy is used for pumps circulating the water to the top of the cooling tower and the operation of fans for forced air induction when the demand for cooling increases. An environmentally sustainable method to achieve heat exchange is to use the stable ground temperature as a heat sink. This is ideal in South Africa where ground temperatures are stable below a certain ground depth. The configuration of the geothermal heat sink loop requires minimal energy to keep the condenser water moving and there is no water loss due to evaporation, Figure 3. 


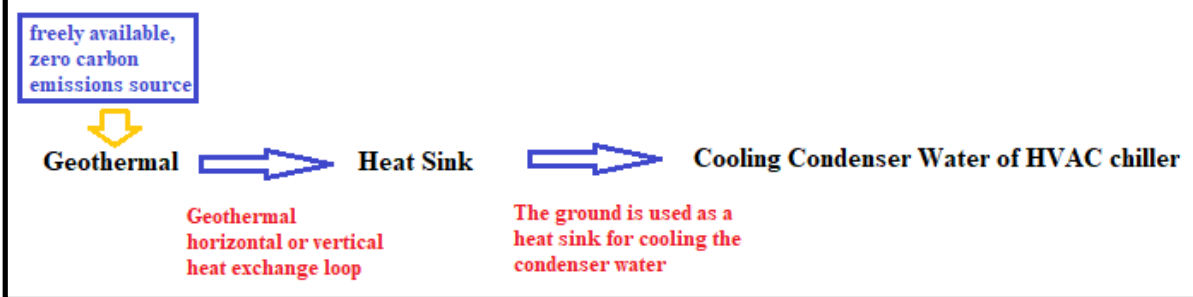

Figure 3: Geothermal Heat Sink used as an Energy Source to Cool the Condenser Water of Air Conditioning Systems.

Using solar heat as an energy source for HVAC absorption chillers with water as refrigerant and geothermal heat sinks in the place of cooling towers saves significantly on electricity and water and eliminates greenhouse gas emissions associated with conventional refrigerants. This type of system could be the most environmentally sustainable HVAC system that can be built with existing commercial technology and materials. It will also be most energy efficient in that when cooling is required, the energy to bring about that cooling is abundantly available.

\subsection{Taking a Holistic Approach to Achieve Energy Efficiency}

Taking a holistic approach to achieving energy efficiency and ensuring that the energy efficiency principles identified are captured in a "Standards and Guidelines for Energy Efficiency" document according to [2] is the next step in ensuring a site's energy efficiency. These steps are captured across principle two and principle three as follows:

"Principle Two: Take a holistic/systems approach when it comes to energy efficiency; this means considering the energy consuming device or technology, the system that the device or technology is a part of as well as factors affecting the system and factors affected by the system.

Principle Three: Ensure that the approach to implementation of energy efficiency meets business imperatives and supports operations based on "Standards and Guidelines for Energy Efficiency". These standards and guidelines must include device types, system types and preferred designs that will apply when new buildings and facilities are constructed, and replacement cycles for existing buildings and facilities..."

The following sections take a holistic approach to the significant energy users of airports, i.e., lighting, HVAC, pumps, motors, fans and "building architecture and envelope". The "building architecture and envelope" impacts the demand for lighting and HVAC. The following sections will take a holistic/systems approach defining energy efficiency guiding statements that must be adopted by all users of the site. These guiding statements were derived for the airports and are clauses contained in their "Standards and Guidelines for Energy Efficiency"which are being implemented as a company policy for all new infrastructure, refurbishments and replacement projects.

\section{(c)Lighting Systems}

Lighting requirements within buildings are regulated by South African National Standards and the Occupational Health and Safety Act 85 of 1993. Minimum lighting levels are specific and are legally binding in South Africa. It is a common practice for emphasis to be placed on the lighting technology being chosen, and other design factors of the lamp and its surroundings are usually neglected. Factors that affect the light output such as the luminaire, control gear and factors that affect the amount of light required such as the colour of paint, furnishings and surroundings are not always considered (figure 4). 


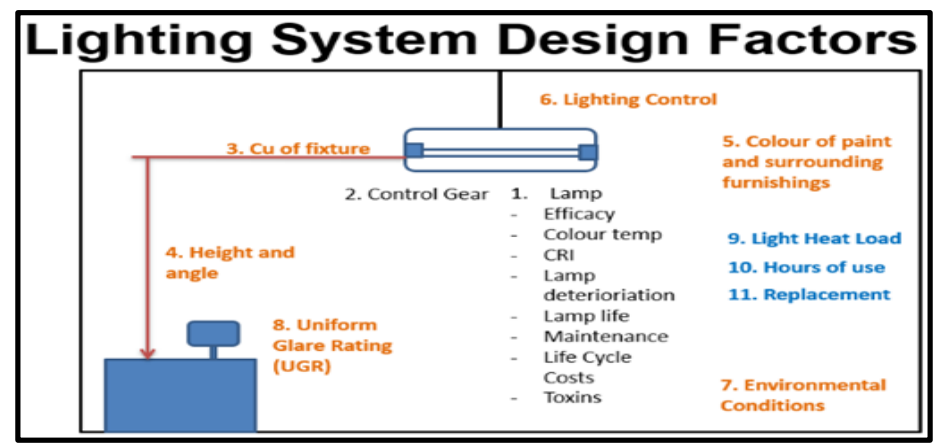

Figure 4: Lighting System Design Factors.

The following energy efficiency guiding statements referred to as "clauses" due to the "Standards and Guidelines for Energy Efficiency” being drafted according to the ISO format supports the organization's financial, technological, and other business imperatives considering the risks, operational and maintenance requirements including practicality of its implementation. These clauses are derived from the lighting design factors presented in figure 4 . The clauses guide new capacity projects, i.e., new office developments, expansions to terminal buildings and other commercial buildings being constructed at the airports to incorporate energy efficiency. The clauses are indicated in italics and the supporting information is not in italics.

- LED lighting technology shall be used for all applications with respect to lighting and illumination.

- LED lighting having a Correlated Colour Temperature above 4000 Kelvin shall only be utilized in areas of transit and is limited to 5600K. Operational areas are recommended to have LED lighting with a Correlated Colour Temperature of $4000 \mathrm{~K}$.

- $\quad$ Lamps with a colour rendition index (CRI) of less than 65 shall not be used.

Colour Rendering Indices (CRI) categories are as follows:

- 75 to $100 \mathrm{CRI}$ - excellent colour rendition

- 65 to $75 \mathrm{CRI}$ - good colour rendition

- $\quad$ under $65 \mathrm{CRI}$ - poor colour rendition

(a) Lamp Efficacy shall be Greater than 80 Lumens per Watt

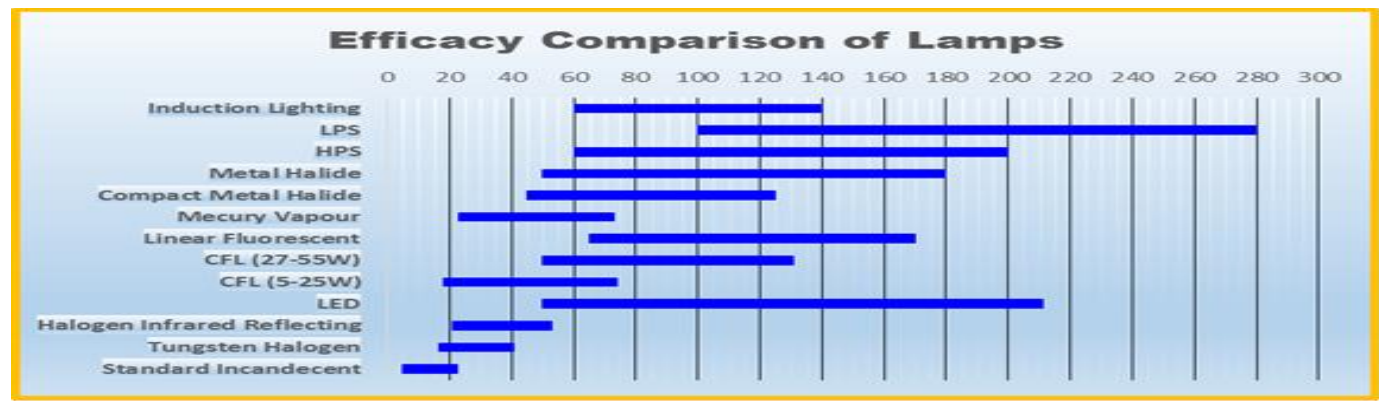

Figure 5: Efficacy Comparison of Lamps [4].

Figure 5 shows a comparison of lighting technologies and their efficacy ranges and that LED lighting has one of the best efficacies of the lighting technologies. The Low Pressure Sodium (LPS) lighting technology which is indicated to 
have an efficacy that outperforms LED lighting has a poor CRI and is a popular choice for street lighting. Figure 6 shows the LED lamp key criteria and how these compare with other lighting technologies.

\begin{tabular}{|c|c|c|c|c|c|c|}
\hline Lamp type & $\begin{array}{l}\text { Luminous } \\
\text { efficacy } \\
\text { (lumens/ } \\
\text { watt) }\end{array}$ & $\begin{array}{l}\text { Luminous } \\
\text { output } \\
\text { (lumens) }\end{array}$ & Wattage & $\begin{array}{l}\text { CCT(घ) } \\
\text { (typical/ } \\
\text { dominant } \\
\text { wavelength }\end{array}$ & $\mathrm{CR}^{(0)}$ & Lifetime \\
\hline $\begin{array}{l}\text { LED white } \\
\text { package (cool) }\end{array}$ & $132 \mathrm{Im} / \mathrm{W}$ & $139 \mathrm{~lm}$ & $1.05 \mathrm{~W}$ & $6500 \mathrm{~K}$ & 75 & $50 \mathrm{k}$ hours \\
\hline $\begin{array}{l}\text { LED white } \\
\text { package (warm) }\end{array}$ & $78 \mathrm{Im} / \mathrm{W}$ & $87.4 \mathrm{Im}$ & $1.12 \mathrm{~W}$ & $3150 \mathrm{~K}$ & 80 & $50 \mathrm{k}$ hours \\
\hline LED lamp (warm) & $62 \mathrm{Im} / \mathrm{W}$ & $650 \mathrm{~lm}$ & $10.5 \mathrm{~W}$ & $3000 \mathrm{~K}$ & 92 & $50 \mathrm{k}$ hours \\
\hline OLED panel & $23 \mathrm{Im} / \mathrm{W}$ & $15 \mathrm{Im}$ & $0.65 \mathrm{~W}$ & $2800 \mathrm{~K}$ & 75 & $5 k$ hours \\
\hline $\begin{array}{l}\text { HID (c) (high watt) } \\
\text { lamp } \\
\text { system }\end{array}$ & $\begin{array}{l}120 \mathrm{Im} / \mathrm{W} \\
111 \mathrm{Im} / \mathrm{W}\end{array}$ & $37800 \mathrm{Im}$ & $\begin{array}{l}315 W \\
341 W\end{array}$ & $3000 \mathrm{~K}$ & 90 & $20 \mathrm{k}$ hours \\
\hline $\begin{array}{l}\text { Linear fluorescent } \\
\text { lamp } \\
\text { system }\end{array}$ & $\begin{array}{l}111 \mathrm{Im} / \mathrm{W} \\
97 \mathrm{Im} / \mathrm{W}\end{array}$ & $\begin{array}{l}2890 \mathrm{Im} \\
5220 \mathrm{Im}\end{array}$ & $\begin{array}{l}26 \mathrm{~W} \\
54 \mathrm{~W}\end{array}$ & $4100 \mathrm{~K}$ & 85 & $25 \mathrm{k}$ hours \\
\hline $\begin{array}{l}\text { HID (low watt) } \\
\text { lamp } \\
\text { system }\end{array}$ & $\begin{array}{l}104 \mathrm{Im} / \mathrm{W} \\
97 \mathrm{Im} / \mathrm{W}\end{array}$ & $7300 \mathrm{IM}$ & $\begin{array}{l}70 \mathrm{~W} \\
75 \mathrm{~W}\end{array}$ & $3000 \mathrm{~K}$ & 90 & $12 \mathrm{k}$ hours \\
\hline CFL & $63 \mathrm{Im} / \mathrm{W}$ & $950 \mathrm{~lm}$ & $15 \mathrm{~W}$ & $2700 \mathrm{~K}$ & 82 & $12 \mathrm{k}$ hours \\
\hline Halogen & $20 \mathrm{~lm} / \mathrm{W}$ & $970 \mathrm{~lm}$ & $48 \mathrm{~W}$ & $2750 \mathrm{~K}$ & N/A & $4 \mathrm{k}$ hours \\
\hline Incandescent & $15 \mathrm{~lm} / \mathrm{W}$ & $900 \mathrm{~lm}$ & $60 \mathrm{~W}$ & $3300 \mathrm{~K}$ & 100 & $1 \mathrm{k}$ hours \\
\hline
\end{tabular}

Figure 6: U.S. Department of Energy Comparison of Lumens per Watt for Various Lamp Types [5]

Figure 6 shows that LEDs provide the most illumination, quality and have the longest lifespan for the least amount of power input.

\section{(b) LED}

Lamps shall only be eligible to be purchased from suppliers offering a five (5) year warranty as a minimum. It is recommended that LED lamps be replaced when their lumen depreciation is at $20 \%$, which corresponds to $80 \%$ lumen output, and fluorescent lamps be replaced when their lumen depreciation is at $20 \%$, which corresponds to $80 \%$ lumen output.

This clause is due to lamp life and lamp deterioration which depends on the type of microchip that is contained in the LED. There are two classes of microchips contained in LED lamps, one is a substandard efficiency microchip contained in lamps of suppliers who do not offer warranties and a premium efficiency microchip which usually carries a warranty of five (5) years. Refer to figure7 for the Lumen Maintenance Curve for various light types.

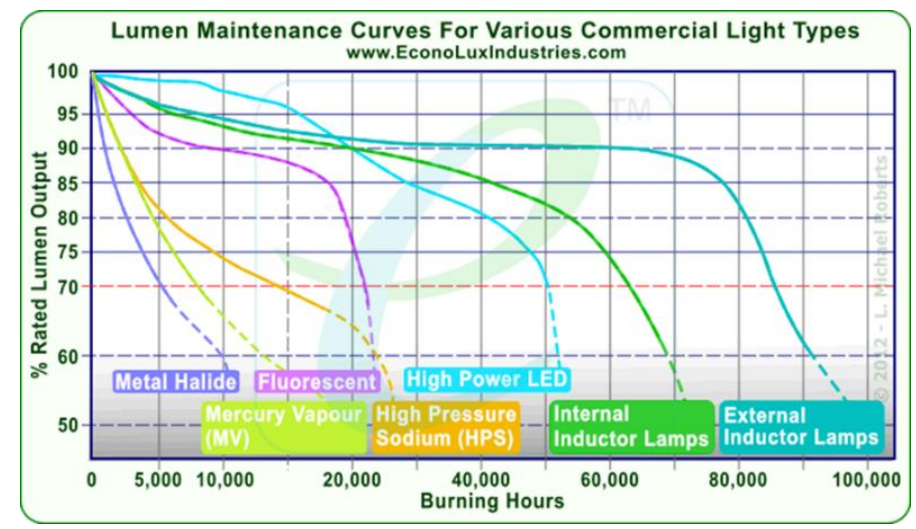

Figure 7: Lumen Maintenance Curves [6]

\section{(c)Technologies that have Toxic Components shall be Avoided}

Compact Fluorescent Lamps (CFLs) have mercury, phosphors, yttrium, etc. that harm the environment and therefore may 
have special disposal requirements which carry significant cost. CFLs exhibit at least 2.5-times and 1.3-times higher human and eco-toxicity potentials than the LEDs, respectively.[7]

(d) Magnetic ballasts shall not be used. A ballast factor as close as possible to 1 shall be accepted with the lower boundary being a ballast factor of 0.95 .

Electronic ballast factors range from 0.7 to 1.2 and are categorized as follows:

- $\quad 0.7$ to 0.8 - Low ballast factor

- $\quad 0.85$ to 1 - Normal ballast factor

- 1.13 to 1.2 - High ballast factor

- For offices, boardrooms and ablution facilities, lighting shall be controlled according to human occupancy using occupancy sensors that adoptpassive infrared and ultrasonic (dual) technology. For indoor passages and walkways, lighting shall be controlled according to motion using occupancy sensors that use passive infrared technology. For car park areas, lighting shall be controlled according to human occupancy, using sensors that increase lighting levels to $100 \%$ in human presence and decrease lighting levels to $40 \%$ in human absence. Street lighting shall be controlled by photocells according to the daylight levels available. All new projects and infrastructure refurbishments must incorporate a Digital Addressable Lighting Interface (DALI) that controls lighting according to demand. For lighting replacements during maintenance, this is a recommendation.

- $\quad$ Uniform Glare Rating (UGR) for lighting systems shall comply with ISO 8995.

- Interior furnishings shall have a ceiling reflectance $(R C)$ of not less than $80 \%$ and wall reflectance $(R W)$ of not less than $70 \%$.

Figure 8 shows the coefficients of utilization in a room that has ceilings and walls in relationship to the room cavity ratio $(\mathrm{RCR})$.

\begin{tabular}{|c|c|c|c|c|c|c|c|c|c|c|}
\hline \multicolumn{5}{|c|}{$\begin{array}{l}\text { Report LS1 } 1101 \\
\text { Lamp: } 400 \text { Watt Clear } \\
\text { Lumens: } 50,000 \\
\text { Mounting Surface/Pendant }\end{array}$} & \multicolumn{6}{|c|}{$\begin{array}{c}\text { COEFFICIENTS } \\
\text { OF UTILIZATION } \\
\text { Zonal Cavity Method } \\
\text { Effective Floor Cavity } \\
\text { Reflectance } 0.20 \\
\end{array}$} \\
\hline $\mathrm{RC}$ & & 80 & & & 70 & & & & & \\
\hline RW & 70 & 50 & 30 & 70 & 50 & 30 & 50 & 30 & 50 & 30 \\
\hline 1 & 94 & 91 & 89 & 91 & 88 & 86 & 83 & 81 & 78 & 77 \\
\hline 2 & 88 & 84 & 80 & 86 & 81 & 78 & 77 & 74 & 73 & 71 \\
\hline 3 & 83 & 77 & 72 & 80 & 75 & 70 & 71 & 67 & 67 & 65 \\
\hline 4 & 78 & 71 & 65 & 75 & 69 & 64 & 66 & 61 & 63 & 59 \\
\hline$\underset{\check{Z}}{ }$ & 73 & 65 & 59 & 70 & 63 & 58 & 60 & 56 & 58 & 54 \\
\hline 6 & 68 & 58 & 52 & 66 & 58 & 52 & 55 & 51 & 53 & 49 \\
\hline 7 & 63 & 54 & 48 & 61 & 53 & 47 & 51 & 46 & 49 & 44 \\
\hline 8 & 59 & 49 & 43 & 57 & 48 & 43 & 46 & 41 & 45 & 40 \\
\hline 9 & 55 & 45 & 39 & 53 & 44 & 38 & 42 & 37 & 41 & 36 \\
\hline 10 & 51 & 41 & 35 & 49 & 40 & 35 & 39 & 34 & 37 & 33 \\
\hline
\end{tabular}

Figure 8: Photometric Table[4].

$$
R C R=\frac{2.5 \times h \times \text { room perimeter }}{\text { room area }}
$$

Where: 
$R C R$ is the room cavity ratio

$h$ is the room height

- In the case of lighting heat sinks for LED lamps being contained in the ceiling voids, return air systems shall not be taken from ceiling voids.

Lighting internal heat gains from non-industrial facilities are typically between $70 \%$ and $400 \%$ that of internal heat gains from people in a typical office space.[9]

- $\quad$ The life of LED lighting shall be a minimum of 50000 burning hours, except for the removable bulb type as in the GU10, MR16, pin-type and Edison screw type which shall be a minimum of 25000 hours.

- For ease of maintenance and replacements, lighting installed in areas that are double volume and more shall incorporate a winch or similar mechanism that drops the light fitting down to a height reachable at floor level with a ladder for maintenance purposes, thus negating the need for other plant and machinery to reach up to the light fitting.

- Lighting for architectural and ambiance purposes shall follow the requirements in this document.

- All advertising, illumination and signage shall follow the requirements set out in this document.

\section{HVAC Systems}

Ventilation requirements are regulated by the Occupational Health and Safety Act 85 of 1993 and SANS 10400 Part O is used in designing of HVAC systems for commercial applications. Much effort is placed on ensuring that the HVAC system'scoolingand heating delivery meets the demand. This is usually the starting point of HVAC system design. The factors that affect the HVAC demand such as the orientation of the building and the envelope design, the windows and doors (fenestration) are not always addressed to effectively reduce the demand. HVAC design should start when the facility under construction is in planning stages. Figure 9 shows the HVAC system design factors.

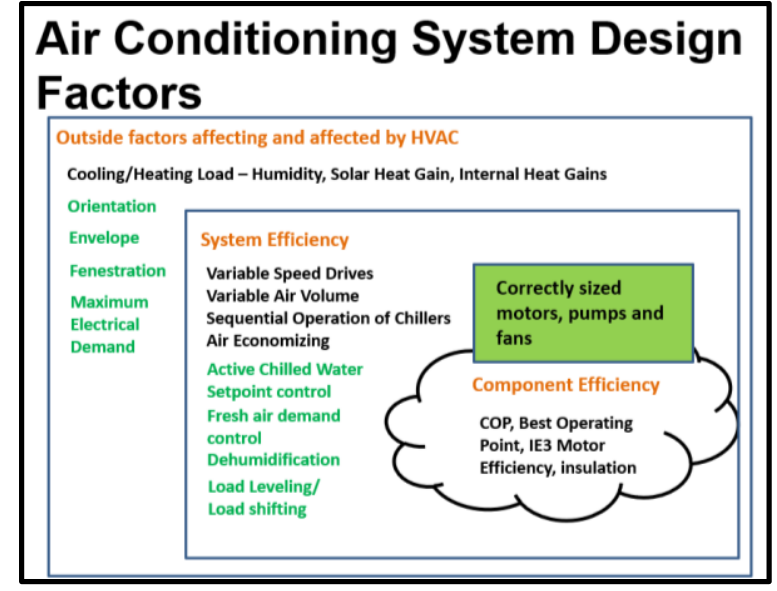

Figure 9: HVAC System Design Factors.

The following statements regarding the designing of HVAC systems are meant to guide projects for incorporation of energy efficiency in HVAC systems.

- To reduce HVAC demand, the following passive cooling interventions must be incorporated for all new buildings 
and refurbishments:

- Double glazing or low emissivity glass

- Wind lobbies designed to reduce the amount of outside air entering the air-conditioned space through building entrances/exits

- Use of heat deflective paint to reduce the amount of solar thermal heat gain through the roof and brick/masonry walls.

- Low building overhangs designed to deflect solar thermal gain and yet allow a certain amount of outdoor lighting to reduce daytime lighting demand.

- All centralized HVAC systems shall incorporate fresh air demand control via Air Handling Units (AHUs) to accurately satisfy oxygen requirements within the space.

- All centralized HVAC systems shall incorporate air economizing which is "free air cooling".

- $\quad$ Return air shall be ducted and taken directly from the space and not filtered through the ceiling void; return air temperature shall be measured in the space.

- All centralized space cooling HVAC systems shall integrate Constant Air Volume (CAV) and Variable Air Volume $(V A V)$ for cooling and heating load profiles in the terminal building. CAVs should be used to satisfy the cooling or heating base load whereas VAVs shall supply varying demand. This clause does not apply to air conditioning systems supplying IT core rooms and wire centres.

Figure 10 shows the rationale behind constant air volume and variable air volumefeeds. The cooling baseload is the load that is required to always be served and the variable cooling load is meant to be served on demand. Choosing constant air volume and variable air volume in design allows for energy efficient design and technology selection of motors and fans.

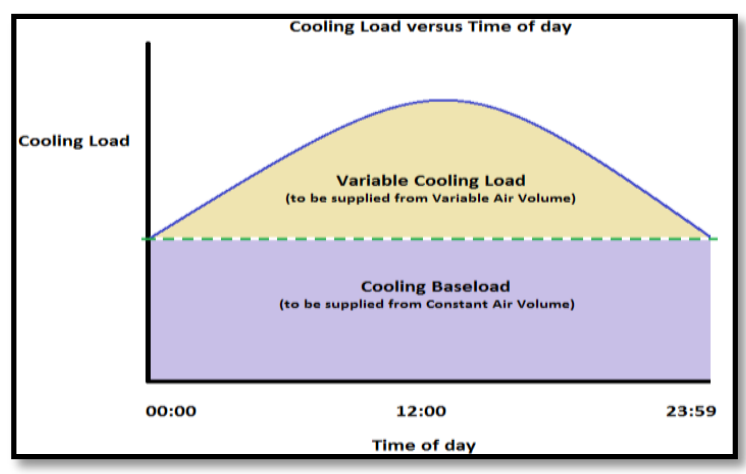

Figure 10: Cooling Load Profile and Type of Air Supply.

- All offices, whether on decentralized or centralized HVAC systems, shall be VAV and all fan coil units and other systems shall be variable refrigerant volume or variable chilled water flow.

- All decentralized systems shall incorporate inverter control for compressor-driven systems to ensure that varying HVAC demand is efficiently satisfied, and the energy rating shall not be less than the " $A$ rating" as per the energy efficiency labelling system. 
- All double volume buildings or structures shall be served from centralized HVAC systems.

- $\quad$ For all new buildings / infrastructure, a centralized HVAC system shall reuse condensate at the cooling towers of water-cooled HVAC systems.

- It is recommended that heat recovery from the condenser be considered for reuse according to a cost-benefit analysis. This cost-benefit analysis must be performed, and its results must be discussed and proven not viable with specific data in respect of the application.

- All centralized HVAC systems shall incorporate active chilled water set point control.

- Constant flow chilled water systems shall not be used in any air conditioning system.

- Variable speed drives shall be used to control chilled water flow as opposed to throttling.

There are various methods for controlling chilled water flow. The most common of these are depicted in Fig.11. Throttling involves restricting the outlet flow of a pump and it is commonly achieved by partially closing a valve, this is similar to controlling speed of a motor vehicle with a foot on the brake at constant accelerator position. Bypassing requires installation of piping to divert part of the outlet which is commonly put back into the inlet. A variable speed drive controls the pump to deliver according tothe need of the system.

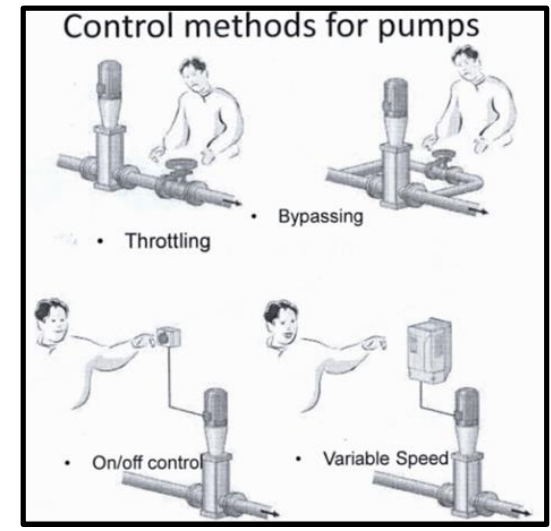

Figure 11: Illustration of Control Methods for Pumps [4].

The difference in these methods of control is the power consumption. Figure 12 illustrates the difference in power consumption between throttling and using a variable speed drive. Figure 13 compares the power consumption of all four methods of control for pumps.

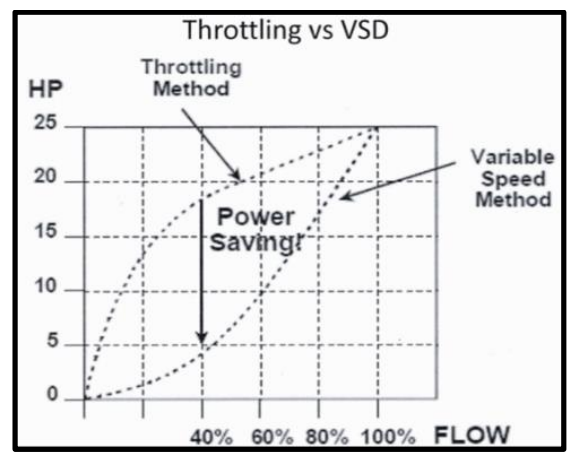

Figure 12: Power Saving with using a Variable Speed Drive Control Instead of Throttling [4]. 
From figure 12 it is evident that there is significant energy saving using a variable speed drive to control flow as opposed to the throttling method, with the largest saving being around the $40 \%$ flow mark.

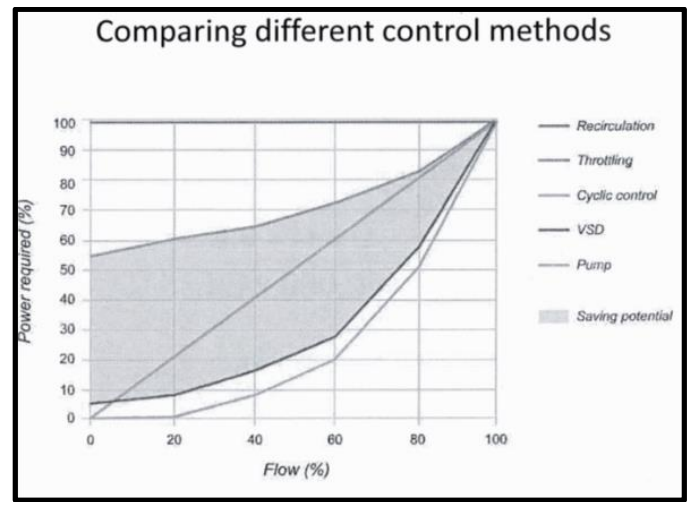

Figure 13: Power Consumption for Various Control Methods for Pumps [4].

From figure 13, it can be seen that the energysaving between the use of VSDs and recirculation, throttling, and cyclic control is significant.

- To satisfy additional cooling demand, the chiller loading methodology for centralized HVAC systems shall be to start the next chiller only once the running chiller/s has exceeded $90 \%$ load and there is yet demand to be satisfied.

- All feedback control sensors shall be strategically placed to measure the respective parameter correctly and accurately.

- It is recommended that all HVAC systems performing dehumidification consider achieving this by using heat pipe dehumidification. This recommendation must be considered by way of a study done for the application showing the merits through a cost-benefit analysis.

Refer to Figure 14 for the depiction of the heat pipe dehumidification process. Heat pipes may be described as having two sections: precool and reheat. The first section is located in the incoming air stream. When warm air passes over the heat pipes, the refrigerant vaporizes, carrying heat to the second section of heat pipes, placed downstream. Because some heat has been removed from the air before encountering the evaporator coil, the incoming air stream section is called the precool heat pipe. Air passing through the evaporator coil is assisted to a lower temperature, resulting in greater condensate removal. The "overcooled" air is then reheated to a comfortable temperature by the reheat heat pipe section, using the heat transferred from the precool heat pipe. This entire process of precool and reheat is accomplished with no additional energy use. The result is an air conditioning system with the ability to remove $50 \%$ to $100 \%$ more moisture than regular systems. 


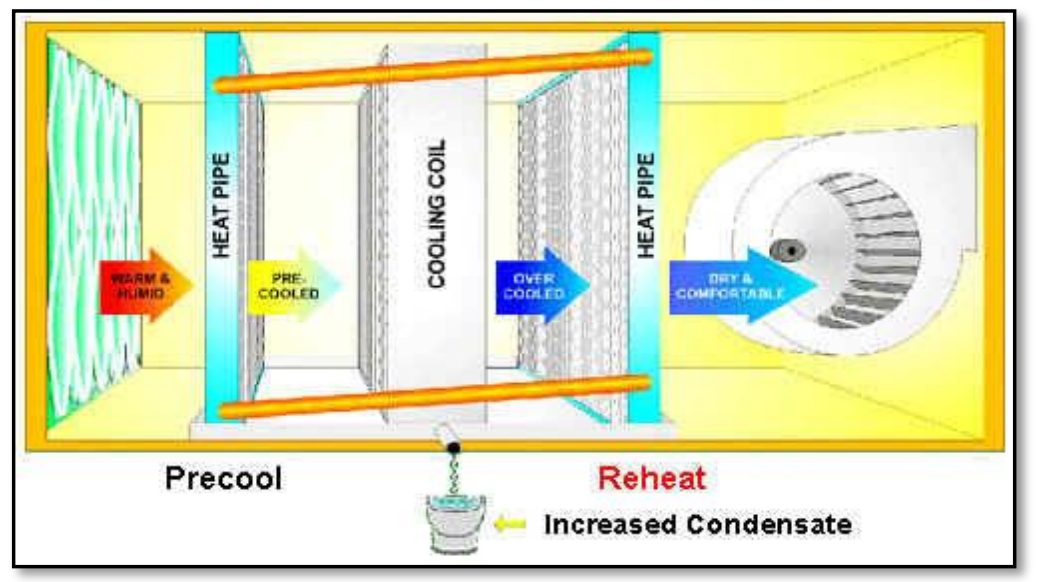

Figure 14: Heat Pipe Dehumidification Process[10].

- If the Coefficient of Performance (COP) of the chiller is less than 2, replacing or reconditioning of the chiller to achieve higher COPs shall be done based on the useful lifespan.

- New buildings and developments shall consider incorporation of alternative energy sources for space cooling or heating needs according to a cost-benefit analysis. This cost-benefit analysis is mandatory and the alternatives that must be considered are heat-pump systems for smaller and decentralized systems, and solar-thermal powered absorption cooling for larger systems (demand of $32 \mathrm{~kW}$ and over).

- Air-cooled and water-cooled HVAC systems shall be chosen on a cost-benefit analysis. The cost benefit-analysis must be performed and discussed before a decision is made.

- Chilled water piping systems and air ducting systems must be adequately insulated and maintained.

- Provision for active measurement of duct air losses shall be made to monitor air leaks.

- In air handling units (AHUs), variable speed drives (VSDs) shall be used as opposed to damping.

There are various ways to control electric motors for variable air flow. Four of these ways are illustrated in figure 15:

- Outlet damper control (location 1),

- Inlet vane control (location 2),

- Magnetic clutching (location 3) and

- Variable frequency drives (location 4)

The typical power consumption of these various control systems can be seen in figure 16. The increase of fan pressure or air flow can be achieved by the arrangement of fans in series or in parallel. A series arrangement will result in an increase in fan pressure and a parallel arrangement will result in an increase in air flow. This can be seen in figure 17. 


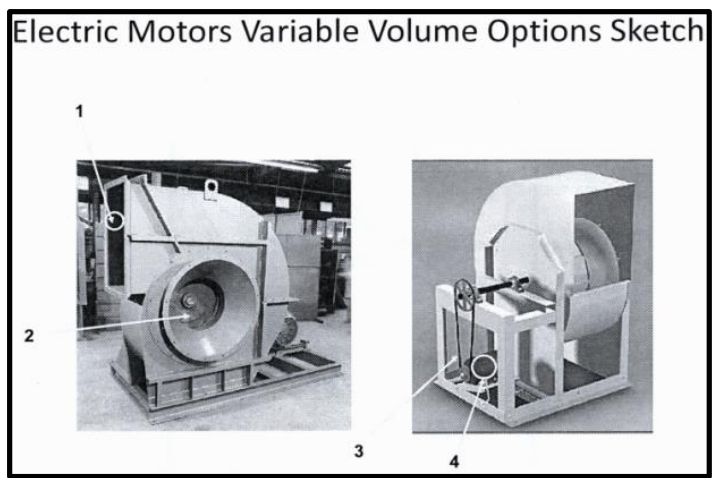

Figure 15: Illustration of Variable Air Control Options[4].

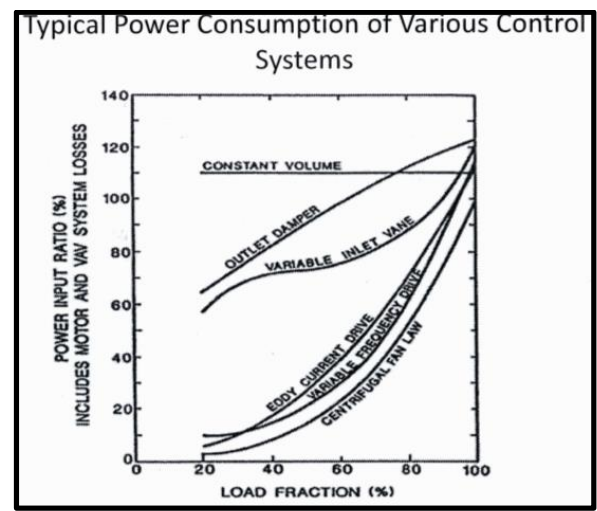

Figure 16: Power Consumption of Variable Air Control Options [4].

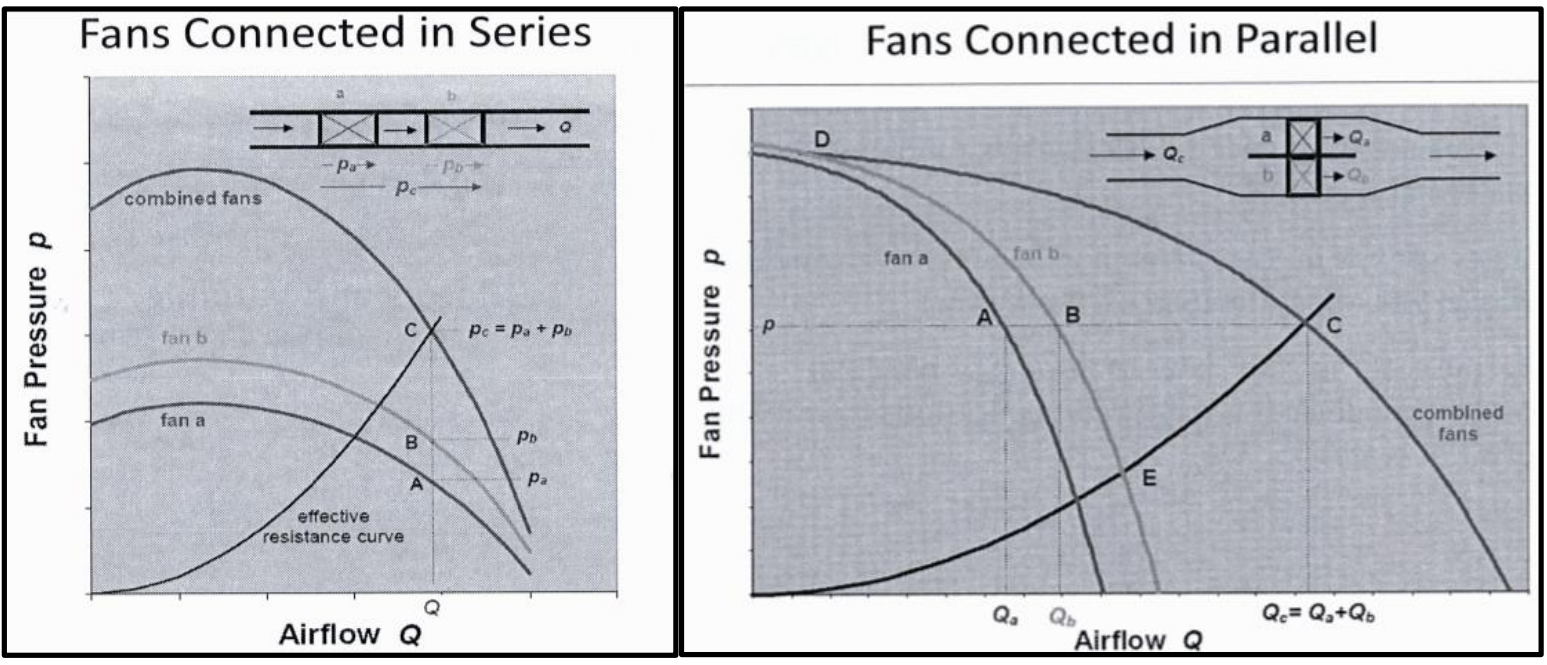

Figure 17: Fans Connected in Series (left) and Parallel[4].

- $\quad$ AHUs shall incorporate filter pressure drop gauges that shall be locally monitored via BMS with alarm remotely.

\section{Pumps}

At airports, the selection of pumps for pumping potable water, sewerage, stormwater, fuel (Jet A1, diesel), fire-fighting systems, and HVAC working fluids, are usually "unseen" and selected at design stage of all facilities. Often in commercial applications, a pump's operation and selection are not re-assessed and modified for its operation. The following clause and supporting information ensures that when pumps are selected for facilities and applications, they are correctly sized for 
operations, ensuring energy efficiency for all pumping applications.

- For pump selection, critical requirements such flow rate and/or pressure head must be established, and selection of pump shall consider the energy consumption implications.

If a pump is producing more pressure than the application requires, it is also consuming more energy than necessary. Elimination of excess energy consumption can be done by reducing the diameter of the pump impeller to the minimum needed to satisfy the pressure or flow requirement. Trimming the impeller of a centrifugal pump reduces its pressure output, rather than its flow capacity. In many applications, impeller trimming can be used to reduce excess flow as well as excess pressure. Refer to Fig. 18.

For example, in designing a pumping system, it is calculated that the system needs a flow rate of 800GPM and that the pump must produce a pressure of 60 feet of head at this flow rate. These pressure and flow rate requirements are marked by Point " $\mathrm{A}$ " in Fig.18. Based on this, a pump with a pump curve "B" is selected. When the system is in operation, the actual system curve turns out to be "C", so the pump actually operates at point " $\mathrm{D}$ ". At this point, the pump pressure is approximately the same as originally estimated, however, the flow rate is much higher than the system requires. Pump power is proportional to the third power of the flow rate, so a large amount of energy is wasted.[11] The centrifugal fan and pump laws can be found below.

Power (kW) and Flow rate (LPS):

$$
\frac{k W_{\text {new }}}{k W_{\text {old }}}=\frac{\left[L P S_{\text {new }}\right]^{3}}{\left[L P S_{\text {old }}\right]^{3}}
$$

LPS: Litres per second

kW: Kilowatt

Power (kW) and pump impeller diameter (D):

$$
\frac{k W_{\text {new }}}{k W_{\text {old }}}=\frac{\left[D_{\text {new }}\right]^{3}}{\left[D_{\text {new }}\right]^{3}}
$$

Pressure or Head (P) and Speed (RPM):

$$
\frac{P_{\text {new }}}{P_{\text {old }}}=\frac{\left[R P M_{\text {new }}\right]^{2}}{\left[R P M_{\text {old }}\right]^{2}}
$$

RPM: Revolutions per minute

Flow (LPS) and Speed (RPM):

$$
\frac{L P S_{\text {new }}}{L P S_{\text {old }}}=\frac{R P M_{\text {new }}}{R P M_{\text {old }}}
$$




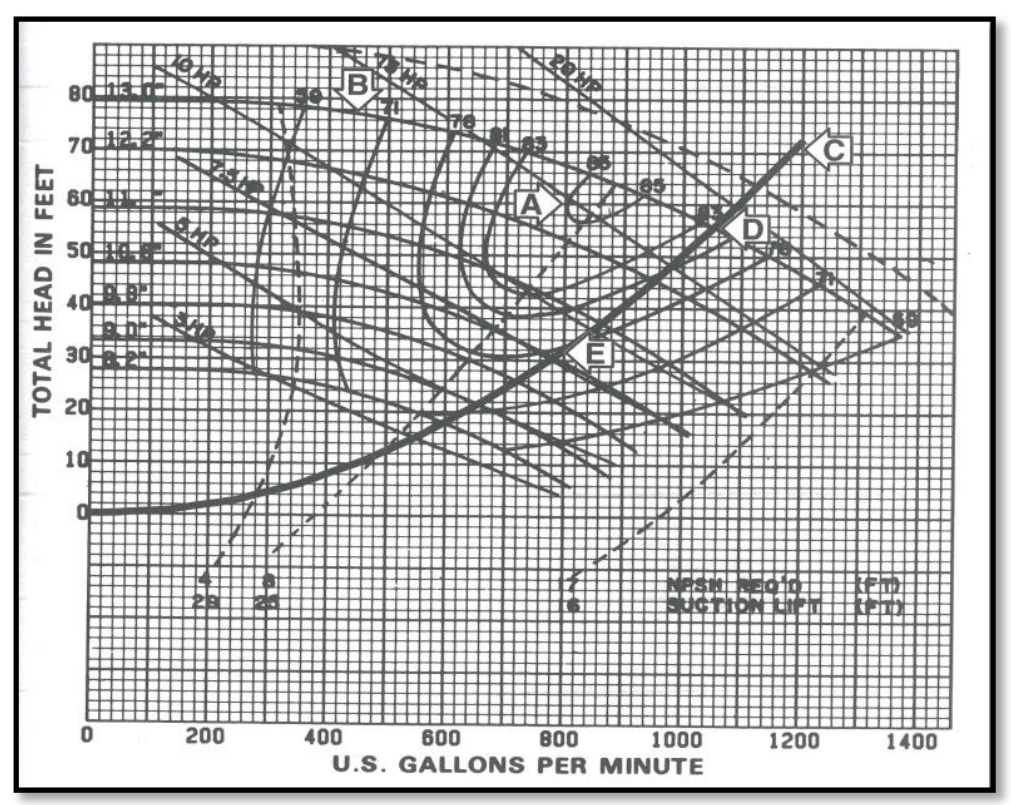

Figure 18: Graph of Pump Impeller Trimming[11].

To eliminate the energy waste, trim the pump impeller so that the pump operates at point "E". This produces the originally required flow rate of $800 \mathrm{GPM}$, but the pump is able to operate at a lower pressure. The pump curves show that the pumping power has been reduced from about 18 horsepower to about 8 horsepower, this amounts to a reduction of net energy by half, taking some efficiency loss in the pump motor into account. Trimming the impeller usually reduces the efficiency of a pump to an extent. Provided that the diameter reduction is not excessive, the efficiency loss is moderate and the reduction in pump power consumption is substantial. In the example above, the pump efficiency was reduced from $82 \%$ to about $77 \%$, but the overall energy consumption was reduced by half. Pump impeller trimming is worthwhile if the application needs only a small reduction of impeller diameter. [11]

One can also increase either the flow rate or the pump head while keeping the other parameters constant by the pump series and parallel arrangements seen in the figure 19.

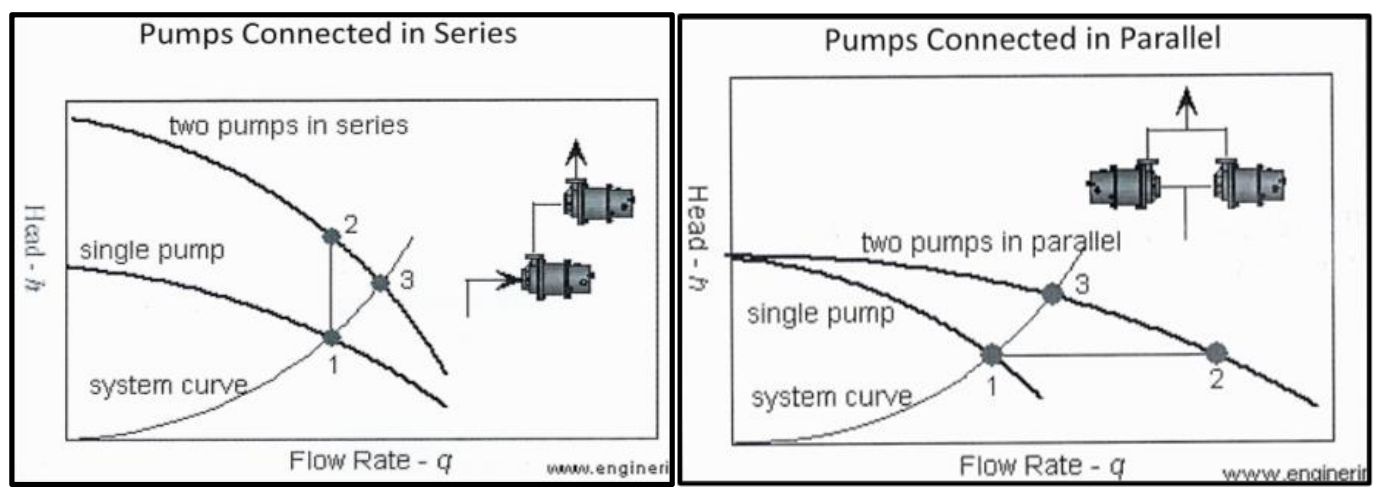

Figure 19: Pumps Connected in Series and Parallel [4].

\section{Motors}

Motor selection is key to saving energy in pump and fan applications at airports. The following section contains the clauses for optimum motor selection together with its supporting information.

- $\quad$ Optimum motor efficiency shall be derived at design stage. 
- If motor output is less than $1 \mathrm{~kW}$, motor with efficiency class of International Efficiency 1(IE1) shall not be used. If motor output is greater than $10 \mathrm{~kW}$ for a system operating for under 2000 hours per year, motors with the efficiency class of IE1 shall be used.In the case of operation hours exceeding 2000 hours per year, motors with efficiency class of IE1 shall not be used.

The International Electro-technical Commission (IEC) has introduced standards relating to energy efficient motors. IEC 60034-30-1 defines four IE (International Efficiency) classes for all electric motors that are rated for sinusoidal voltage. Standard efficiency is IE1, High efficiency is IE2, Premium efficiency is IE3 and Super premium efficiency is IE4. Figure 20 shows the correlation between efficiency and output for the four efficiency classes of motors.

To achieve the best return on investment, users of production equipment need to apply a life cycle approach when considering investing in major equipment. The life cycle cost (LCC) is the total cost for purchasing, installing, operating, maintaining and disposing of an item of machinery. Life cycle costing comparisons can be seen in Figure 21. Motor selection at design stage shall be such that it operates at not less than 50\% load, but not more than $100 \%$. Active system control shall be achieved by using a variable speed drive. The standard IEC 60034-30-1:2014 defines efficiency levels and classes at $50 \mathrm{~Hz}$ and $60 \mathrm{~Hz}$ for single or three-phased line motors (regardless of the technology).

\section{International Efficiency 1, 2, 3, 4}

- $\quad$ Number of poles: $2,4,6,8$

- $\quad$ Power range: $0.12 \mathrm{~kW}$ to $1.000 \mathrm{~kW}$

\section{$\underline{\text { Level }}$}

- IE1 - Standard Efficiency

- $\quad$ IE2 - High Efficiency

- $\quad$ IE3 - Premium Efficiency

- $\quad$ IE4 - Super Premium Efficiency

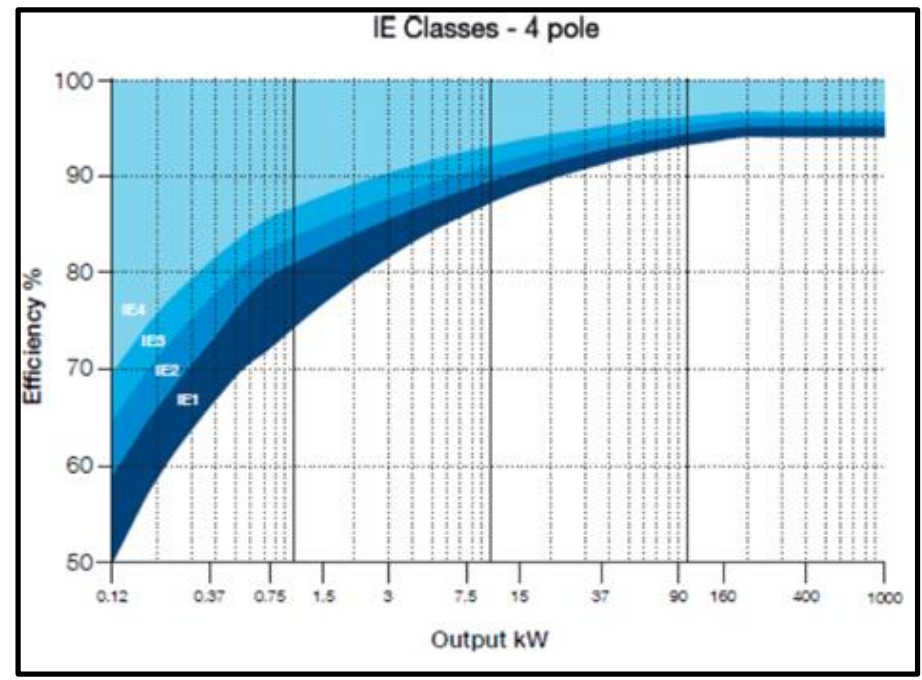

Figure 20: Motor IE Classes and their Efficiencies in Relation to the Power Output[12]. 


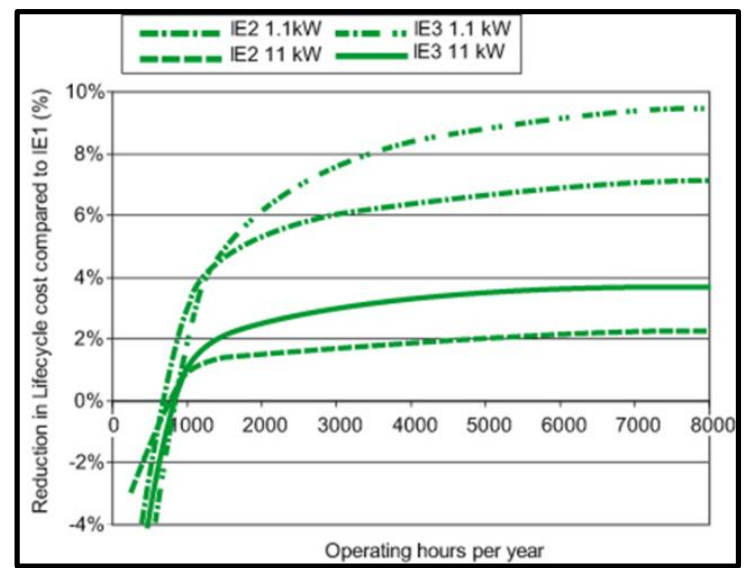

Figure 21: Life Cycle Cost Comparisons for Motor Classes IE1, IE2 and IE3 [13].

At 1000 hours operation, IE2 and IE3 motors give about the same percent reduction in LCC compared to IE1.At 8000 hours operation, IE2 and IE3 percent reduction in LCC compared to IE1 increases to its maximum and thereafter flattens out.

\section{Building Architecture and Envelope}

The building architecture and envelope is the key to reducing energy demand for lighting and air conditioning. Airport terminal buildings in South Africa are at least double volume and this represents a significant lighting and HVAC demand. In South Africa, the SANS 204 energy efficiency standard contains guidelines on building architecture and envelope design. Airports can benefit immensely from the research that supports the clauses in the SANS 204 energy efficiency standard. The following three clauses serve to guide new capacity building projects design of orientation, envelope,and fenestration at airports.

- The orientation of new buildings shall comply with the optimal building orientation set out in SANS 204: 2011, clauses 4.1 and 4.2 .

- $\quad$ The envelope of new buildings shall comply with the building design set out in SANS 204: 2011, clauses 4.3.2, 4.3.3, 4.3.5, 4.3.6 and 4.4.

- $\quad$ The fenestration of new buildings shall comply with the requirements for fenestration set out in SANS 204: 2011, clause 4.3.4.

Ensuring that the Approach to Implementation of Energy Efficiency Meets Business Imperatives

The successful implementation of energy efficiency within a business requires effective integration into existing business processes, communication with executing stakeholders and decision makers, and ensuring its adoption in projects. Airports by nature have multiple stakeholders including airlines, ground handlers, maintenance service providers, operators, concessionaires, government agencies, retailers, and others. The effective implementation and relevance of energy efficiency is the final principle in energy efficiency according to [2].

Principle Three: Ensure that the approach to implementation of energy efficiency meets business imperatives and supports operations based on "Standards and Guidelines for Energy Efficiency". These standards and guidelines must include device types, system types and preferred designs that will apply when new buildings and facilities are constructed, and replacement cycles for existing buildings and facilities. 
The following sections contain the steps taken toward effective implementation of energy efficiency to ensure that all airports transform to be energy efficient facilities over a defined period of time.

\section{Implementation plan for Integrating the Standards and Guidelines for Energy Efficiency}

Now that there is a "Standards and Guidelines for Energy Efficiency" that is adopted as a company policy with clauses that guide the technology selection and design of the significant energy users at airports is the key that the policy is implemented effectively.

Identifying the implementers of the policy and the area that it will be implemented in is key to the success of integrating energy efficiency into the business. One must have a thorough understanding of how the business works and the governance processes. Table 1 shows the key implementers and the area of implementation at ACSA.

Table 1: Identification of Implementers of the Standards and Guidelines for Energy Efficiency

\begin{tabular}{|l|l|}
\hline \multicolumn{1}{|c|}{ Key Implementers of the Policy } & \multicolumn{1}{c|}{ Area of Implementation } \\
\hline Project Managers and User Clients & Capital Projects \\
\hline Operational expenditure budget owners & Refurbishments Projects \\
\hline Maintenance Engineering Contract Managers & Service Level Agreements \\
\hline Tenant Contract Managers & Tenant Lease Agreements \\
\hline Airport Planners & Airport Planning activities \\
\hline Chief Engineers & Technology Selection and Standards Development \\
\hline Environmental Compliance Officers & Auditsof environmental compliance \\
\hline Supply Chain Management & Life Cycle Costing Approach \\
\hline Operations Staff & Daily Operations Requirements \\
\hline Operational Service Providers & Service Level Agreements \\
\hline
\end{tabular}

Once the implementers and the area of implementation have been identified, a communication strategy must be prepared for each stakeholder. It is advised that communication be arranged for one group of stakeholders at any time so that communication can be contextualized for their area of implementation. Table 2 shows the communication plan that was executed per stakeholder grouping for the nine airports owned and operated by ACSA in South Africa.

Table 2: Communication Plan with Various Stakeholder Groupings

\begin{tabular}{|l|l|l|}
\hline \multicolumn{1}{|c|}{ Stakeholder Grouping } & \multicolumn{1}{|c|}{$\begin{array}{c}\text { Target Date of Policy } \\
\text { Communication }\end{array}$} & \multicolumn{1}{c|}{$\begin{array}{c}\text { Person } \\
\text { Responsible }\end{array}$} \\
\hline $\begin{array}{l}\text { Portfolio Project Management in Technical Services } \\
\text { and solutions }\end{array}$ & 13 June to 31 August 2017 & Jerusha Joseph \\
\hline $\begin{array}{l}\text { Maintenance Engineering in Infrastructure Asset } \\
\text { Management }\end{array}$ & 13 June to 31 August 2017 & Jerusha Joseph \\
\hline Spatial portfolio (Property, Commercial, Advertising) & 13 June to 31 August 2017 & Jerusha Joseph \\
\hline Supply Chain Management & 13 June to 31 August 2017 & Jerusha Joseph \\
\hline Finance & 13 June to 31 August 2017 & Jerusha Joseph \\
\hline Environmental Compliance & 13 June to 31 August 2017 & Jerusha Joseph \\
\hline Operations in Airport Management & 13 June to 31 August 2017 & Jerusha Joseph \\
\hline Airport Planning & 13 June to 31 August 2017 & Jerusha Joseph \\
\hline Chief Engineers & 13 June to 31 August 2017 & Jerusha Joseph \\
\hline
\end{tabular}

\section{Implementing Energy Efficiency in Projects}

To effectively implement energy efficiency in projects, various energy efficiency actions must be introduced at each stage in the project life cycle. Table 3 shows the various project actions that must be taken at general project stages for each implementing function within ACSA. The red text within table 3 indicates the actions regarding energy efficiency that must be taken. There are various forms of project life cycles when it comes to executing infrastructure projects. Table 4 
gives the energy efficiency actions at each project stage including the role players for five different project life cycles, i.e., the South African National Treasury, the Engineering Council of South Africa (ECSA), the South African Councils for Quantity Surveying, Project Management, Architectural professions, Construction and Industry Council, ISO 29481-1 and Royal Institute of British Architects Plan of Work.

Table 3: Actions Required by Projects being Executed by Various Departments for Different Project Stages

\begin{tabular}{|c|c|c|c|c|c|c|}
\hline Implementer & $\begin{array}{l}\text { Stage 1: } \\
\text { Inception }\end{array}$ & $\begin{array}{c}\text { Stage 2: } \\
\text { Preliminary } \\
\text { Design }\end{array}$ & $\begin{array}{l}\text { Stage 3: } \\
\text { Detailed } \\
\text { Design }\end{array}$ & $\begin{array}{c}\text { Stage 4: } \\
\text { Documentation } \\
\text { and } \\
\text { Procurement }\end{array}$ & $\begin{array}{c}\text { Stage 5: } \\
\text { Contract } \\
\text { Management }\end{array}$ & $\begin{array}{l}\text { Stage 6: } \\
\text { Close Out }\end{array}$ \\
\hline $\begin{array}{l}\text { Airport } \\
\text { Planning }\end{array}$ & $\begin{array}{l}\text { Passenger } \\
\text { Traffic } \\
\text { Forecast }\end{array}$ & $\begin{array}{l}\text { Airport } \\
\text { Future } \\
\text { Capacity }\end{array}$ & $\begin{array}{l}\text { Masterplan } \\
\text { Drafting } \\
\text { Action: } \\
\text { Submit } \\
\text { Electrical } \\
\text { Demand } \\
\text { Planning } \\
\text { Request } \\
\text { containing } \\
\text { future } \\
\text { electrical } \\
\text { loads and } \\
\text { consider } \\
\text { orientation of } \\
\text { future } \\
\text { infrastructure }\end{array}$ & & & \\
\hline $\begin{array}{l}\text { Infrastructure, } \\
\text { Information } \\
\text { Technology, } \\
\text { Security, } \\
\text { Refurbishment, } \\
\text { Projects }\end{array}$ & \multicolumn{6}{|c|}{ Refer to Table 4 following } \\
\hline $\begin{array}{l}\text { Maintenance } \\
\text { Projects }\end{array}$ & $\begin{array}{l}\text { Business } \\
\text { Case } \\
\text { Action: } \\
\text { Application } \\
\text { of Standards } \\
\text { and } \\
\text { Guidelines } \\
\text { for Energy } \\
\text { Efficiency }\end{array}$ & $\begin{array}{l}\text { Project } \\
\text { Charter } \\
\text { Action: } \\
\text { Applications } \\
\text { of Standards } \\
\text { and } \\
\text { Guidelines } \\
\text { for Energy } \\
\text { Efficiency }\end{array}$ & $\begin{array}{l}\text { Procurement } \\
\text { based on } \\
\text { Demand } \\
\text { Request }\end{array}$ & $\begin{array}{l}\text { NEC/ECC \& } \\
\text { TSC (3-5 years) } \\
\text { Action: } \\
\text { Applications of } \\
\text { Standards and } \\
\text { Guidelines for } \\
\text { Energy } \\
\text { Efficiency }\end{array}$ & $\begin{array}{l}\text { Project } \\
\text { Execution and } \\
\text { Service Level } \\
\text { Agreements } \\
\text { (SLAs) }\end{array}$ & $\begin{array}{l}\text { Measurement } \\
\text { and } \\
\text { Verification } \\
\text { (continuous } \\
\text { evaluation of } \\
\text { SLAs) } \\
\text { Action: } \\
\text { Measurement } \\
\text { and } \\
\text { Verification } \\
\text { exercise to } \\
\text { determine } \\
\text { energy } \\
\text { savings and } \\
\text { effectiveness } \\
\text { of the } \\
\text { standard }\end{array}$ \\
\hline
\end{tabular}




\begin{tabular}{|c|c|c|c|c|c|c|}
\hline $\begin{array}{l}\text { Spatial } \\
\text { Agreements }\end{array}$ & $\begin{array}{l}\text { Commercial } \\
\text { Business } \\
\text { Case }\end{array}$ & $\begin{array}{l}\text { Project } \\
\text { Charter } \\
\text { Action: } \\
\text { Application } \\
\text { of Standards } \\
\text { and } \\
\text { Guidelines } \\
\text { for Energy } \\
\text { Efficiency }\end{array}$ & $\begin{array}{l}\text { Procurement } \\
\text { based on } \\
\text { Demand } \\
\text { Request }\end{array}$ & $\begin{array}{l}\text { Tender } \\
\text { Document } \\
\text { Action: Review } \\
\text { of the Tenant's } \\
\text { Energy } \\
\text { Management } \\
\text { Strategy and } \\
\text { submit Electrical } \\
\text { Load Request to } \\
\text { Electrical } \\
\text { Department }\end{array}$ & $\begin{array}{l}\text { Contract } \\
\text { Negotiation } \\
\text { and Signing }\end{array}$ & $\begin{array}{l}\text { Contract } \\
\text { Management } \\
\text { Action: } \\
\text { Measurement } \\
\text { and } \\
\text { Verification } \\
\text { exercise to } \\
\text { determine } \\
\text { energy } \\
\text { savings and } \\
\text { effectiveness } \\
\text { of the } \\
\text { standard }\end{array}$ \\
\hline
\end{tabular}

Table 4: Energy Efficiency Actions and Role Players at Each Stage Gate for the Various Project Life Cycles

\begin{tabular}{|c|c|c|c|c|c|c|c|c|}
\hline \multirow{3}{*}{$\begin{array}{l}\text { ACSA } \\
\text { responsible } \\
\text { party }\end{array}$} & \multirow{3}{*}{$\begin{array}{c}\text { Standards and } \\
\text { Guidelines for Energy } \\
\text { Efficiency }\end{array}$} & \multicolumn{7}{|c|}{ Local and International Project Life Cycle Standards } \\
\hline & & & $\begin{array}{l}\text { National Treasury } \\
\text { (2015) }\end{array}$ & $\begin{array}{l}\text { Engineering Council } \\
\text { South Africa (ECSA) }\end{array}$ & \begin{tabular}{|} 
SA Councils for the \\
quantity surveying \\
profession (SACQSP), \\
Project and construction \\
management professions \\
(ACPCMP), landscape \\
and architectural \\
profession (SACLAP) and \\
architectural profession \\
(SACAP)
\end{tabular} & $\begin{array}{l}\text { Construction } \\
\text { Industry Council } \\
\text { (2007) }\end{array}$ & $\begin{array}{l}\text { ISO 29481-1 } \\
\text { (2010), Building } \\
\text { Information } \\
\text { Modelling }\end{array}$ & $\begin{array}{l}\text { Royal Institute } \\
\text { of British } \\
\text { Architects Plan } \\
\text { of Work (2013) }\end{array}$ \\
\hline & & $\begin{array}{c}\text { Stage } \\
\text { number }\end{array}$ & \multicolumn{6}{|c|}{ Project Life Cycle Stages } \\
\hline $\begin{array}{l}\text { Planning/Spatial } \\
\text { functions }\end{array}$ & $\begin{array}{c}\text { Considered at planning } \\
\text { stage for cost estimation } \\
\text { and where capacities are } \\
\text { available, notification of } \\
\text { enablement of Electrical, } \\
\text { Sewer and water supply } \\
\text { services } \\
\end{array}$ & 0 & Project Inception & & & & $\begin{array}{l}\text { Portfolio } \\
\text { Requirements }\end{array}$ & \\
\hline Planning functions & & 1 & $\begin{array}{c}\text { Infrastructure } \\
\text { planning }\end{array}$ & & & & & \\
\hline Planning functions & & 2 & Strategic resourcing & & & & & \\
\hline \multirow{2}{*}{$\begin{array}{l}\text { Engineering and } \\
\text { User Client }\end{array}$} & \multirow{2}{*}{$\begin{array}{l}\text { Implemented at Scoping } \\
\text { Stage }\end{array}$} & \multirow[b]{2}{*}{3} & \multirow{2}{*}{$\begin{array}{l}\text { Preparation and } \\
\text { briefing or } \\
\text { prefeasibility }\end{array}$} & \multirow[t]{2}{*}{ Inception } & \multirow[b]{2}{*}{ Inception } & \multirow[b]{2}{*}{ Preparation } & Concept of need & Strategic design \\
\hline & & & & & & & Outline feasibility & $\begin{array}{c}\text { Preparation and } \\
\text { brief }\end{array}$ \\
\hline \multirow{2}{*}{$\begin{array}{c}\text { Project } \\
\text { Management }\end{array}$} & \multirow{2}{*}{$\begin{array}{l}\text { Implemented at Feasibility } \\
\text { Stage }\end{array}$} & \multirow{2}{*}{4} & \multirow{2}{*}{$\begin{array}{c}\text { Concept and viability } \\
\text { or feasibility }\end{array}$} & \multirow{2}{*}{$\begin{array}{l}\text { Concept and viability } \\
\text { (preliminary design) }\end{array}$} & \multirow{2}{*}{ Concept and viability } & \multirow{2}{*}{ Concept } & $\begin{array}{c}\text { Substantive } \\
\text { feasibility }\end{array}$ & \\
\hline & & & & & & & $\begin{array}{c}\text { Outline conceptual } \\
\text { design }\end{array}$ & \\
\hline $\begin{array}{l}\text { Project } \\
\text { Management }\end{array}$ & $\begin{array}{c}\text { Check implementation of } \\
\text { Standards and Guidelines } \\
\text { for Energy Efficiency in the } \\
\text { design and Electrical Load } \\
\text { request submitted to the } \\
\text { Engineering department } \\
\text { and inclusion of an energy } \\
\text { meter } \\
\end{array}$ & 5 & Design development & $\begin{array}{l}\text { Design development } \\
\text { (detailed design) }\end{array}$ & Design development & $\begin{array}{l}\text { Design } \\
\text { development }\end{array}$ & $\begin{array}{l}\text { Full conceptual } \\
\text { design }\end{array}$ & Developed design \\
\hline \multirow{2}{*}{$\begin{array}{c}\text { Project } \\
\text { Management and } \\
\text { Engineering }\end{array}$} & \multirow{2}{*}{$\begin{array}{c}\text { Check inclusion of } \\
\text { Standards and Guidelines } \\
\text { for Energy Efficiency -Final } \\
\text { Sign off on Tender } \\
\text { preparation }\end{array}$} & \multirow{2}{*}{$6 \mathrm{~A}$} & \multirow{2}{*}{$\begin{array}{l}\text { Production } \\
\text { information }\end{array}$} & \multirow{2}{*}{$\begin{array}{l}\text { Documentation and } \\
\text { procurement }\end{array}$} & \multirow{2}{*}{$\begin{array}{l}\text { Documentation and } \\
\text { procurement }\end{array}$} & \multirow{2}{*}{$\begin{array}{l}\text { Production } \\
\text { information }\end{array}$} & $\begin{array}{c}\text { Coordinated design } \\
\text { and procurement }\end{array}$ & \multirow{3}{*}{ Technical design } \\
\hline & & & & & & & $\begin{array}{l}\text { Production } \\
\text { information }\end{array}$ & \\
\hline $\begin{array}{c}\text { Project } \\
\text { Management }\end{array}$ & & $6 B$ & $\begin{array}{c}\text { Manufacture, } \\
\text { fabrication and } \\
\text { construction } \\
\text { information }\end{array}$ & & & $\begin{array}{l}\text { Manufacture, } \\
\text { fabrication and } \\
\text { construction } \\
\text { information }\end{array}$ & \multirow{4}{*}{ Construction } & \\
\hline $\begin{array}{c}\text { Project } \\
\text { Management }\end{array}$ & & 7 & Works & $\begin{array}{l}\text { Contract administration } \\
\text { and inspection }\end{array}$ & \multirow[b]{2}{*}{ Construction } & & & Construction \\
\hline $\begin{array}{l}\text { Project } \\
\text { Management, } \\
\text { Engineering and } \\
\text { User Client }\end{array}$ & \begin{tabular}{|} 
Evaluation of Energy Saved \\
as per anticipation at \\
feasibility stage - excel \\
spreadsheet of all Energy \\
consuming equipment \\
specifications handed over \\
to the Engineering \\
department
\end{tabular} & 8 & Handover & & & \multirow[t]{2}{*}{$\begin{array}{l}\text { Post Practical } \\
\text { completion }\end{array}$} & & \multirow[t]{2}{*}{$\begin{array}{l}\text { Handover and } \\
\text { close-out }\end{array}$} \\
\hline $\begin{array}{c}\text { Project } \\
\text { Management }\end{array}$ & $\begin{array}{l}\text { Handover documentation } \\
\text { for all energy using } \\
\text { infrastructure }\end{array}$ & 9 & Close out & Close-out & Close-out & & & \\
\hline Engineering & $\begin{array}{l}\text { Energy measurement after } \\
\qquad 1 \text { year }\end{array}$ & & & & & & & In use \\
\hline
\end{tabular}


Awareness must be created throughout the organization, including technical support and guidance for the implementation of the standards and guidelines for energy efficiency.

\section{CONCLUSIONS}

The most energy efficient, low carbon energy sources for the airports in South Africa owned and operated by ACSA for their identified significant energy users (lighting and space air conditioning) were presented. The most energy efficient, low carbon energy source for lighting according to the best available technologies on market is solar energy through photovoltaic technology with energy storage. For space air conditioning chillers solar thermal energy as a power source energizing absorption chiller technology and for the cooling towers utilizing stable ground temperature as a heat sink through geothermal heat sink, are the most energy efficient low carbon energy sources.

A holistic/systems approach in the form of a Standards and Guidelines for Energy Efficiency for new infrastructure and refurbishments was presented in relation tothe airports' significant energy users,including energy efficiency clauses addressing technology choices, specifications and design features for lighting, HVAC, pumps, motors, building architecture and envelope. Implementing alternative energy sources requires an in-depth analysis that considers the airports' electrical demand, their operations and organizational prerogatives. When alternative energy is considered for the airports, the energy efficiency pathways established in this paper will be taken into consideration.

\section{REFERENCES}

1. K. Syngellakis, S. Taylor, M. Draeck, et.al., "Sustainable Energy Regulation and Policymaking forAfrica”, UNIDO Training Package, Module 18, http://africa-toolkit.reeep.org/, accessed 05 December 2020.

2. J. Joseph, F.L. Inambao, "Principles for Achieving Energy Efficiency in Developing Countries", International Journal of Mechanical and Production Engineering Research and Development (IJMPERD), ISSN (P): 2249-6890; ISSN (E): 2249 8001, Vol. 11, Issue 2, Apr 2021, 265-282.

3. J. Joseph, F.L. Inambao, "Energy Consumption and Energy Efficiency of Airports: A Case Study of Airports in South Africa", International Journal of Mechanical and Production Engineering Research and Development (IJMPERD), ISSN (P): 22496890; ISSN (E): 2249-8001, Vol. 11, Issue 2, Apr 2021, 205-228.

4. Zikhali, W. Perspectives of Infrastructure Development: An Analysis of Three Wards in Nkayi District, Zimbabwe

5. American Association of Energy Engineers (AEE), 2014, Certified Energy Manager Course notes.

6. DOE Solid-State Lighting Research and Development: Multi-Year Program Plan.

7. http://www.econoluxindustries.com/Technology.html, accessed 28th April 2015.

8. http://www.electronicstakeback.com/2013/01/16/new-research-shows-cfls-and-led-lightbulbs-have-higher-toxicity-andresource-depletion-than-incandescent, accessed 28th April 2015.

9. $\quad$ http://www.standardpro.com/ballasts-infolfluorescent-ballasts/terminology, accessed 29th April 2015.

10. http://www.electronicstakeback.com/2013/01/16/new-research-shows-cfls-and-led-lightbulbs-have-higher-toxicity-andresource-depletion-than-incandescent, accessed 28th April 2015.

11. Khatun, Y., \& Ghosh, S. Spatial Disparities in Health Care Infrastructure in South 24 Parganas District of West Bengal, India.

12. http://www.asoinc.com/applications/DH/DHHeatPipe.html, accessed 29th April 2015. 
Implementation of Energy Efficiency for Airports in South Africa

13. Energy Efficiency Manual, by Donald R. Wulfinghoff, Page 1178 - 1179.

14. Motor Guide February 2014, Low voltage Motors, ABB, ISBN 952-91-0728-5.

15. http://www.electrical-installation.org/enwiki/Energy_saving_opportunities_-_Motors, accessed 29th April 2015. 
